\title{
Szakmapolitika, de miért és hogyan?
}

Szendrei Kálmán, Tóth Barbara, Csupor Dezsö*

Szegedi Tudományegyetem, Farmakognóziai Intézet, 6720 Szeged, Eötvös u. 6.

*e-mail: csupor.dezso@pharmacognosy.hu

Az utóbbi néhány évben a gyógynövényalkalmazás egyre szélesebb körűvé válását számos, tudatlanságból vagy merkantil szellem által vezérelt szakszerútlenség kíséri. Miután ez a jelenség csak egyike a társadalomban ma tömegesen jelenlévő hasonló tendenciáknak, fennáll annak a veszélye, hogy a rendcsinálás jogos igénye egy nagyobb kezdeményezés részeként olyan helyzetet teremthet, amelyben a közhangulatot és a szabályokat mélyebb szakmai ismeretek és megfontolások nélkül alakítják. Ennek első, sporadikus jelei már korábban is megjelentek éles vitákat generálva.

Annak érdekében, hogy a gyógynövényekkel kapcsolatos viták, szabályozási próbálkozások a szakmailag kívánatos módon folyjanak, proaktív magatartásra van szükség a gyógynövényekkel foglalkozó szakemberek részéről. A munka részesei tágabb körben a gyógyszerészek, akik a gyógynövényekkel kapcsolatos ismeretek közvetítői, az attitǔd formálói a lakosság felé. A tervezésben és koordinációban kiemelt szerep hárul az MGYT Gyógynövény Szakosztályra. Az előadás felvázolja magát a jelenséget, annak negatív aspektusait és bemutatja a cselekvés lehetőségeit. 